\title{
Lactic Acid Bacteria Cause a Leaf Blight and Bulb Decay of Onion (Allium cepa)
}

Jean M. Bonasera, Jo Ann E. Asselin, and Steven V. Beer, Section of Plant Pathology and Plant-Microbe Biology, School of Integrative Plant Sciences, Cornell University, Ithaca, NY 14853, U.S.A.

\begin{abstract}
Several members of the lactic acid bacteria group were isolated from diseased onion plants and bulbs. Based on growth characteristics and sequence analysis of $16 \mathrm{~S}$ rRNA and rpoA genes, the strains were identified as Lactococcus lactis, Lactobacillus plantarum, and three species of Leuconostoc, i.e., citreum, mesenteroides, and pseudomesenteroides. Pathogenic potential to onion leaves and mature onion bulbs was

assessed. L. plantarum and all three Leuconostoc species caused symptoms in both leaves and bulbs. L. lactis caused scale discoloration in bulbs but failed to cause lesions on leaves. Leuconostoc citreum caused bulb decay in 7 days at $18^{\circ} \mathrm{C}$ as well as $37^{\circ} \mathrm{C}$. This is the first report of a group of gram-positive bacteria able to cause disease in onion leaves.
\end{abstract}

Onions are a major crop in the United States, with the 2015 crop valued at close to $\$ 1$ billion (United States Department of Agriculture National Agriculture Statistic Service). Annually, growers incur losses due to several fungal and bacterial pathogens; the degree of loss varies considerably from year to year, presumably due to weather conditions. Numerous bacteria are associated with diseases of onion bulbs. Of these, some, such as Xanthomonas axonopodis pv. allii, are restricted to leaves (Schwartz 2008). Others, such as Pantoea ananatis, cause leaf symptoms and can move through leaf tissue and into the bulb, in which they lead to bulb decay (Carr et al. 2013). Isolation of putative pathogens from diseased onion tissue is generally the first step in identifying the cause of bacterial disease. However, complex mixtures of organisms are routinely recovered from diseased onion tissue when general microbiological media are used. This can be problematic, as nonpathogenic environmental organisms can quickly overtake or obscure the presence of slower growing or less-abundant pathogens.

Use of a selective or semiselective medium can be helpful in limiting the number of species recovered (Schaad 2001), and decisions regarding appropriate media are guided by the apparent disease symptoms and the pathogens known to be associated with such symptoms. Because all the known important bacterial pathogens of both onion bulbs and leaves are gram-negative aerobes or facultative anaerobes, selective and semiselective media developed for bacterial isolation from onions generally favor these microbes and contain inhibitors of fungal and gram-positive bacterial growth. However, using selective media carries the risk of excluding a novel pathogen, particularly one that is fastidious in its nutrient requirements or requires atypical growing conditions.

In the course of analyzing commercially grown symptomatic onion plants and bulbs from New York and Oregon between 2013 and 2015 , bacteria were occasionally recovered that failed to thrive on onion extract medium (OEM) (Zaid et al. 2012), a semiselective medium for growth of gram-negative bacteria from onion leaves and bulbs, or Luria-Bertani (LB) agar, a general microbiological medium. Use of a modified version of a medium developed by Elliker (Elliker et al. 1956) to support growth of fastidious organisms improved the rate of growth of some isolates, and the enhanced growth

Corresponding author: S. V. Beer; E-mail: svb1@cornell.edu

*The $\boldsymbol{e}$-Xtra logo stands for "electronic extra" and indicates that one supplementary figure is published online.

Accepted for publication 7 September 2016.

(c) 2017 The American Phytopathological Society of the bacteria facilitated their identification as members of the order Lactobacillales.

The order Lactobacillales contains a diverse group of fastidious microaerophilic gram-positive bacteria referred to as lactic acid bacteria (LAB). They are unified by their ability to produce lactate from glucose by homofermentative or heterofermentative pathways. The order is currently delineated into six families, each with multiple genera (Schleifer 2009). While named for their common ability to produce lactic acid, LAB are distinct even within a species. They have unique and complex nutritional requirements that are suited to their varied ecological niches.

$\mathrm{LAB}$ are ubiquitous in the environment and are valued for their ability to ferment dairy, meat, and vegetables, by which they create many stable food products. They were critical to the preservation of many foodstuffs before the advent of mechanical refrigeration (Ross et al. 2002). Their association with growing plants is considered "neutral" (Van Baarlen and Siezen 2009) and, in some situations, may be beneficial. A recent report from Korea described a Lactobacillus sp. deployed as a biocontrol agent that reduced foliar symptoms of a bacterial spot disease in pepper (Capsicum annuum) plants by nearly $80 \%$ (Shrestha et al. 2014).

Extensive pathogenicity tests on leaves and bulbs indicated that some LAB are capable of causing disease symptoms comparable in extent to those elicited by several gram-negative pathogens in both growing onion leaves and harvested bulbs. This report describes the isolation, identification, and pathogenic ability to onions of several LAB, which had been isolated from symptomatic commercially grown onion plants and bulbs collected from three locations in the United States.

\section{Materials and Methods}

Isolation, culture, and preservation of bacteria from symptomatic onion plants. Symptomatic plants were either processed upon receipt or held under refrigeration for up to two days prior to processing. Each diseased onion plant or bulb was bisected with a disinfested knife and was photographed. Isolations were made by touching a sterile wooden applicator to the margin of the symptomatic tissue and dilution-streaking from the diseased tissue onto an $\mathrm{OEM}$ agar plate. Plates were incubated for $48 \mathrm{~h}$ at $28^{\circ} \mathrm{C}$. Following incubation, individual colonies were chosen and restreaked to purity on either LB or OEM agar plates. Colonies from purified strains were lifted from agar plates, using sterile cotton-tipped swabs, and were released into sterile $15 \%$ (vol/vol) glycerol solutions for preservation at $-80^{\circ} \mathrm{C}$. Once identified, LAB strains were routinely cultured at $37^{\circ} \mathrm{C}$ on lactic-sucrose (LS) agar, a modification of Elliker's lactic agar (Elliker et al. 1956), composed of $20 \mathrm{~g}$ of casein enzymatic hydrolysate (Sigma-Aldrich), $5 \mathrm{~g}$ of yeast extract, $2.5 \mathrm{~g}$ of gelatin from porcine skin (Sigma-Aldrich), $5 \mathrm{~g}$ of sucrose, $4 \mathrm{~g}$ of 
sodium chloride, $0.5 \mathrm{~g}$ of L-ascorbic acid sodium salt, and $18 \mathrm{~g}$ of agar per liter.

Antibiotic resistance assessment. Isolates were streaked on LS agar containing either $50 \mu \mathrm{g}$ of kanamycin or $50 \mu \mathrm{g}$ of vancomycin per milliliter. Bacterial growth was assessed after incubating for 5 days at room temperature.

Genomic DNA extractions. DNA extractions were carried out as described previously (Azcárate-Peril and Raya 2001), with the following modifications: (i) cultures were prepared by incubating for 4 days without shaking at room temperature in LS broth, (ii) antibiotics were supplemented with kanamycin and vancomycin at $50 \mu \mathrm{g} / \mathrm{ml}$ for resistant strains (Table 1), (iii) the procedure was carried out at $1 / 10$ volume in microcentrifuge tubes, (iv) all centrifugations were done at $16,000 \times g$, and (v) the steps following the first DNA precipitation and resuspension, i.e., steps 8 through 12 , were omitted.

Amplification of housekeeping genes. Polymerase chain reaction was carried out using OneTaq DNA polymerase (New England Biolabs, Ipswich, MA). Total reaction volumes were $12.5 \mu \mathrm{l}$ and were composed of $6.7 \mu \mathrm{l}$ of sterile water, $2.5 \mu \mathrm{l}$ of reaction buffer $(5 \times$ $\mathrm{GC}$, supplied with polymerase), $1.0 \mu \mathrm{l}$ of dNTP mix ( $2.5 \mathrm{mM}$ each), $0.6 \mu \mathrm{l}$, each, of the forward and the reverse primers $(10 \mu \mathrm{M}), 0.1 \mu \mathrm{l}$ of polymerase $(5 \mathrm{U} / \mu \mathrm{l})$, and $1.0 \mu \mathrm{l}$ of genomic DNA template. Cycling parameters were $10 \mathrm{~min}$ at $95^{\circ} \mathrm{C} ; 45$ cycles of $30 \mathrm{~s}$ at $95^{\circ} \mathrm{C}, 45 \mathrm{~s}$ at $50^{\circ} \mathrm{C}$, and a 150 -s extension at $65^{\circ} \mathrm{C}$, as noted in Table 2 . A final extension step was done with a single cycle for $10 \mathrm{~min}$ at $72^{\circ} \mathrm{C}$.

Amplicon sequencing. Amplicons were purified using DNA Clean \& Concentrator-5 (Zymo Research Corporation, Irvine, CA), according to the manufacturer's directions, and were sequenced at the Cornell University Life Sciences Core Laboratories in two reactions, one with each amplification primer.

Cultivation of onion plants for leaf pathogenicity tests. Onion plants, variety Hendrix (Stokes Seeds, Ltd. ON, Canada) or Braddock (Bejo Seeds, Inc., Oceana, CA) were grown from seed sown in Pro-Mix BX (Premier Tech Horticulture, Quakertown, PA), in a controlled environment chamber, with dark-cycle temperature of $13^{\circ} \mathrm{C}$ and a light-cycle temperature of $18^{\circ} \mathrm{C}$. The length and intensity of the light cycle was increased as follows: 3 weeks of $12 \mathrm{~h}$ with $200 \mu \mathrm{mol} \mathrm{m}{ }^{-2} \mathrm{~s}^{-1}$ light, followed by 2 weeks of $13 \mathrm{~h}$ with $212 \mu \mathrm{mol}$ $\mathrm{m}^{-2} \mathrm{~s}^{-1}$ light, followed by 2 weeks of $14 \mathrm{~h}$ with $225 \mu \mathrm{mol} \mathrm{m} \mathrm{m}^{-2} \mathrm{~s}^{-1}$ light, followed by 3 weeks of $14 \mathrm{~h}$ with $238 \mu \mathrm{mol} \mathrm{m}^{-2} \mathrm{~s}^{-1}$ light, and finally, $14 \mathrm{~h}$ of $250 \mu \mathrm{mol} \mathrm{m} \mathrm{m}^{-2} \mathrm{~s}^{-1}$ light until inoculation. Plants were bottom-watered with dilute fertilizer containing $4.4 \mathrm{mM}$ $\mathrm{KNO}_{3}, 2 \mathrm{mM} \mathrm{Ca}\left(\mathrm{NO}_{3}\right)_{2}, 1 \mathrm{mM} \mathrm{KH_{2 }} \mathrm{PO}_{4}, 0.5 \mathrm{mM} \mathrm{MgSO}$, $175 \mu \mathrm{M} \mathrm{NH} \mathrm{NHO}_{3}, 62.6 \mu \mathrm{M} \mathrm{K} \mathrm{SO}_{4}, 17 \mu \mathrm{M} \mathrm{Fe}\left(\mathrm{NO}_{3}\right)_{3}, 17 \mu \mathrm{M}$ diethylenetriaminepenta-acetic acid, $15 \mu \mathrm{M} \mathrm{H} \mathrm{H}_{3} \mathrm{BO}_{3}, 3.5 \mu \mathrm{M}$ $\mathrm{ZnSO}_{4}, 2.5 \mu \mathrm{M} \mathrm{MnSO}_{4}, 0.4 \mu \mathrm{M} \mathrm{CuSO}_{4}$, and $0.2 \mu \mathrm{M} \mathrm{Na}_{2} \mathrm{MoO}_{4}$. The amount and timing of fertigation depended on the stage of growth, with the goal of keeping the soil moist but not wet. This method of propagating onion plants provided uniform healthy plants suitable for inoculations at various stages of development from seedling to mature plant.

Pathogenicity tests. Bacterial suspensions were prepared by transferring 1- or 2-day-old colonies growing on LS agar plates into sterile water, using sterile cotton-tipped applicators until an optical densiety at $600 \mathrm{~nm}\left(\mathrm{OD}_{600}\right)$ between 0.2 and 0.3 was reached. $A n \mathrm{OD}_{600}$ of 0.2 contained approximately $10^{8} \mathrm{CFU}$ per milliliter. The toothpick inoculation method described here delivered approximately $5 \mu \mathrm{l}$ of inoculum, resulting in delivery of approximately one million bacterial cells. Plants or bulbs mock-inoculated with sterilized water were used as negative controls.

The following reference strains of gram-negative onion pathogens were used: Burkholderia cepacia type strain ATCC 25416 and Pantoea ananatis OC5a (Carr et al. 2013). Reference strains were cultured on LB agar plates incubated at $37^{\circ} \mathrm{C}$. Inoculum was prepared as described above.

Yellow onion bulbs, purchased at the local supermarket, were surface-disinfested as described by Schroeder et al. (2009). A sterilized wooden toothpick was dipped into inoculum and was then immediately stabbed into the shoulder of a bulb. Three replicated inoculated bulbs were sealed in plastic bags and were incubated for 1 week at $18^{\circ} \mathrm{C}, 28^{\circ} \mathrm{C}$, or $37^{\circ} \mathrm{C}$. Following incubation, bulbs were

Table 1. Source and putative identification of bacterial strains characterized in this study

\begin{tabular}{|c|c|c|c|c|c|c|}
\hline \multirow[b]{2}{*}{ Strain } & \multirow[b]{2}{*}{ Putative identification $^{\mathbf{a}}$} & \multirow[b]{2}{*}{ Antibiotic resistance ${ }^{\mathbf{b}}$} & \multirow[b]{2}{*}{ Source, isolation date } & \multicolumn{2}{|c|}{ Pathogenicity } & \multirow[b]{2}{*}{ Accession numbers ${ }^{\mathrm{e}}$} \\
\hline & & & & Leaf $^{\mathrm{c}}$ & Bulb $^{\mathbf{d}}$ & \\
\hline AP3a & Lactococcus lactis & $\mathrm{Km}$ & Onion leaf, New York, July 2014 & Negative & $-/ \mathrm{w} /+$ & KX286332/KX347971 \\
\hline A1-0015 & Lactococcus lactis & None & Cheese isolate & Negative & $-/+/+$ & KX286330/KX347969 \\
\hline $\mathrm{AH} 2 \mathrm{c}$ & Leuconostoc pseudomesenteroides & $\mathrm{Km}, \mathrm{Vc}$ & Onion leaf, New York, July 2013 & Positive & $\mathrm{w} /+/+$ & KX286331/KX347970 \\
\hline AP8a & Leuconostoc pseudomesenteroides & $\mathrm{Km}, \mathrm{Vc}$ & Onion leaf, New York, July 2014 & Positive & $\mathrm{w} /+/+$ & KX286333/KX347972 \\
\hline AT5 & Leuconostoc mesenteroides & $\mathrm{Km}, \mathrm{Vc}$ & Onion leaf, Oregon, July 2015 & Positive & $-/+/+$ & KX286334/KX347973 \\
\hline R5-0648 & Leuconostoc mesenteroides & $\mathrm{Km}, \mathrm{Vc}$ & $\begin{array}{l}\text { Milk isolate, Idaho, August } 2006 \\
\text { (Ranieri and Boor 2009) }\end{array}$ & Positive & $-/+/+$ & KX286337/KX347976 \\
\hline AT7a & Leuconostoc citreum & $\mathrm{Km}, \mathrm{Vc}$ & Onion leaf, Oregon, July 2015 & Positive & $+/+/+$ & KX286335/KX347974 \\
\hline AZ2 & Lactobacillus plantarum & $\mathrm{Km}, \mathrm{Vc}$ & Onion bulb, New York, September 2015 & Positive & $-/+/+$ & KX286336/KX347975 \\
\hline
\end{tabular}

a Identification based on sequence analysis of rpoA and 16S rRNA genes.

${ }^{\mathrm{b}} \mathrm{Km}=$ kanamycin $(50 \mu \mathrm{g} / \mathrm{ml}) ; \mathrm{Vc}=$ vancomycin $(50 \mu \mathrm{g} / \mathrm{ml})$.

${ }^{\mathrm{c}}$ Positive, strain elicited a leaf lesion after 48 hours incubation at $32^{\circ} \mathrm{C}$; Negative, strain failed to elicit a lesion.

${ }^{\text {d }}$ At $18^{\circ} \mathrm{C} / 28^{\circ} \mathrm{C} / 37^{\circ} \mathrm{C}$. +, water-soaked and discolored; w, occasionally positive; -, bulbs indistinguishable from water controls in all trials.

e 16s rRNA/rpoA.

Table 2. Primers used for amplification and sequencing of lactic acid bacteria

\begin{tabular}{|c|c|c|c|c|}
\hline Target gene and primer & Primer sequence and reference & $\begin{array}{c}\text { Annealing } \\
\text { temperature }\end{array}$ & $\begin{array}{l}\text { Extension time } \\
\text { at } 65^{\circ} \mathrm{C}(\mathrm{min})\end{array}$ & Amplicon size (bp) \\
\hline rpoA & 5'-GGTACRACKYTWGGKAAYTCDYTKCGTCG-3' & $50^{\circ} \mathrm{C}$ & 2.5 & 776 \\
\hline $91 \mathrm{~F}$ & Developed for this study & & & \\
\hline rpoA & 5'-CGMACYTTCATCATRTCRGCTTC-3' & & & \\
\hline $844 \mathrm{R}$ & Developed for this study & & & \\
\hline $16 \mathrm{~S}$ & 5'-AGAGTTTGATCCTGGCTCAG-3' & $50^{\circ} \mathrm{C}$ & 2.5 & 1,513 \\
\hline $8 \mathrm{UA}$ & "fD1" (Weisburg et al. 1991) & & & \\
\hline $16 \mathrm{~S}$ & 5'-ACGGCTACCTTGTTACGACTT-3' & & & \\
\hline T5A & "rP2" (Weisburg et al. 1991) & & & \\
\hline
\end{tabular}


bisected at the inoculation site, were photographed, and were assessed for symptoms.

Onion plants with five to nine leaves that had been grown in a controlled environment chamber were transferred to a $32^{\circ} \mathrm{C}$ incubator, $24 \mathrm{~h}$ before inoculations. Plants were inoculated by stabbing through the adaxial surface of the four youngest leaves, $10 \mathrm{~cm}$ above the soil line, with a toothpick previously dipped in inoculum. Following inoculation, plants were returned to the $32^{\circ} \mathrm{C}$ incubator. Lesion length measurements were made periodically. Plants were dissected after 2 to 3 weeks of incubation.

Bacteria were recovered from symptomatic tissue by one of two methods. The lacuna surfaces of leaf lesions were touched with a sterile applicator stick and were dilution-streaked on LS agar supplemented with kanamycin $(50 \mu \mathrm{g} / \mathrm{ml})$, vancomycin $(50 \mu \mathrm{g} / \mathrm{ml})$, and cylcoheximide $(250 \mu \mathrm{g} / \mathrm{ml})$. Five-centimeter sections of stem, including lesion margins, located on the portion of the plant below the soil line were excised, were surface-disinfested by dipping in $70 \%$ (vol/vol) ethanol and, then, placed on LS agar containing kanamycin $(50 \mu \mathrm{g} / \mathrm{ml})$, vancomycin $(50 \mu \mathrm{g} / \mathrm{ml})$, and cylcoheximide $(250 \mu \mathrm{g} / \mathrm{ml})$, and were incubated for $24 \mathrm{~h}$ at $37^{\circ} \mathrm{C}$. Genomic DNA was prepared from recovered bacteria as described previously and were used as a template in amplification and sequencing of the rpoA gene.

Both leaf and bulb pathogenicity tests were carried out at least three times with three plants or bulbs per strain in each experiment. Leaf pathogenicity tests for well-described pathogens $B$. cepacia and $P$. ananatis were carried out twice.

\section{Results}

Isolation from symptomatic onion plants and bulbs. In July 2013, a Cornell Cooperative Extension Educator headquartered at Albion, NY, near the Elba muck, observed symptoms in onion plants that she characterized as "the first classic bacterial symptoms of the season." On examination in the laboratory, the plants, a red long-day storage onion variety grown from transplants, had blanched and water-soaked center leaves and macerated necks with a vinegarlike odor (Fig. 1A). Three colony types, all very small and nondescript, were recovered from isolations made from symptomatic neck tissue; each type was streaked to purity. Attempts to amplify the strains with gyrB primers (Bonasera et al. 2014) failed; however, the DNA from the strains did amplify with $16 \mathrm{~S}$ rDNA primers (Weisburg et al. 1991) (Table 2). Analysis of the 16S sequence suggested that the three strains represented two different genera, Lactococcus and Leuconostoc, gram-positive bacteria that are members of the group referred to as $\mathrm{LAB}$.

The following year, in July 2014, a concerned grower in Orange County, NY hand-delivered symptomatic plants to Ithaca, NY. The grower reported the plants were of variety Red Wing, grown from seedling transplants. His expressed concern was that his samples constituted a fast moving disease that "when one (plant) gets it and falls on the next plant, that one gets it." The center leaves of the plants were highly symptomatic, some plants had hollow necks and the developing bulbs felt soft. On bisecting, some symptoms stopped at the neck, while others continued into the bulb, in which the center of the bulb was completely macerated (Fig. 1B). An assortment of previously described pathogens was recovered from these plants. Isolations were carried out from 12 plants and B. cepacia and Dickeya sp. were isolated from three plants each. Two plants yielded $P$. ananatis and one plant yielded a strain of Enterobacter ludwigii. The remaining three plants contained bacteria similar to those LAB isolated in the previous year; the colonies were very small and did not amplify with the gyrB primers. The $16 \mathrm{~S}$ sequence from two of the remaining strains suggested they were LAB. The last strain has yet to be identified.

In June 2015, a large onion grower in eastern Oregon reported having two fields of red onions with "plants infected with bacterial disease." Symptomatic plants were shipped via overnight courier to Ithaca, NY, where they were processed on arrival. The center of the bulbs and the associated leaves were severely macerated (Fig. 1C and D). Bacteria with similar characteristics to the gram-positive strains isolated from New York onions in the previous two years, as described above, were recovered from four of eight plants examined.

In September 2015, a grower in Orange Co., NY reported that direct-seeded variety Braddock onions that had just been harvested and "were bone dry; no green at all" had begun to rot, "green tissue in the neck either got cooked and fermented and started down the neck to the bulb." On examination in the lab, the upper neck and bulb tissues were severely macerated, the bulb scales that were still intact appeared water-soaked with yellow-orange discoloration (Fig. 1E).

Identification by sequence analysis of $16 \mathrm{~S}$ rRNA and rpoA. Sequences from portions of the genes encoding 16S rRNA and RNA polymerase subunit A ( $r p o A)$ were used to identify the isolated strains mentioned above. Assembled sequences were used to query the GenBank database. Sequence analysis confirmed that the onion isolates were from three families in the order Lactobacillales: Lactobacillaceae, Leuconostocaceae, and Streptococcaceae. The putative identifications, based on "Best Hit," are listed in Table 1. Strains were identified as Lactococcus lactis, Leuconostoc pseudomesenteroides, Leuconostoc mesenteroides, Leuconostoc citreum, and Lactobacillus plantarum. Multiple sequences have been deposited in GenBank as accession numbers KX286330 to KX286337 and KX347969 to KX347976.

Pathogenicity in onion bulbs. Strains from all three genera caused symptoms of discoloration and water-soaking in inoculated onion bulbs incubated for 1 week at both 37 and $28^{\circ} \mathrm{C}$ (Table 1). The extent of the symptoms varied with strain and was more severe at $37^{\circ} \mathrm{C}$ for all strains. At $18^{\circ} \mathrm{C}$, symptoms varied considerably. Leuconostoc citreum AT7 a caused robust symptoms, while both $L$. lactis strains tested, AP3a and A1-0015, did not cause symptoms when incubated for 1 week.

Pathogenicity in onion leaves. Strains of L. lactis, regardless of isolation source, failed to cause lesions in leaves (Table 1). Plants inoculated with strain AP3a or A1-0015 were indistinguishable from those mock-inoculated with water, even after incubation at $32^{\circ} \mathrm{C}$ for 19 days.

Plants inoculated with onion isolates of any of the three species of Leuconostoc or Lactobacillus plantarum developed leaf lesions within $48 \mathrm{~h}$ of inoculation (Fig. 2, top). Lesions were often discontiguous from the inoculation site and, in some instances, occurred as much as $9 \mathrm{~cm}$ below the inoculation site, extending toward or even into the neck, causing the leaf to collapse. No lesions extended toward the leaf tip. However, once the lesion had girdled the leaf, the upper portion of the leaf became necrotic. The most severely affected leaf was usually the second or third youngest leaf. Older leaves and the very youngest leaves were generally asymptomatic 5 days after inoculation, following incubation of the plants at $32^{\circ} \mathrm{C}$. When incubations were carried out at lower temperatures, 18 and $28^{\circ} \mathrm{C}$, infection rates were low and symptom development was markedly slower (data not shown). Dissection of plants 19 days after inoculation and incubation at $32^{\circ} \mathrm{C}$ revealed lesion extension into the developing bulb tissue (Fig. 2, bottom). Growth characteristics of the bacteria isolated from the lesion margin and sequences of the rpoA gene amplicon matched that of the inoculated strain.

Comparison of pathogenicity of onion isolates to milk isolates in onion bulbs. Symptoms that resulted from inoculation of strains of the same species of LAB isolated from either onions or dairy products were similar in mature onion bulbs (Supplementary Fig. S1).

Comparison of virulence of LAB to gram-negative onion pathogens in onion leaves. When strains of $B$. cepacia and $P$. ananatis were compared side-by-side to LAB in leaf pathogenicity assays at $32^{\circ} \mathrm{C}$, both $B$. cepacia and $P$. ananatis caused symptoms on all inoculated leaves in $48 \mathrm{~h}$, regardless of leaf age. Some strains of LAB caused a similar degree of damage to individual leaves but to only one or two of the inoculated leaves.

\section{Discussion}

In this study, six strains of LAB isolated from diseased onions and two strains isolated from dairy products caused disease of onions in artificial inoculation experiments. Strains identified as Lactococcus lactis, Leuconostoc mesenteroides, Leuconostoc pseudomesenteroides, 
Leuconostoc citreum, and Lactobacillus plantarum caused water soaking and discoloration, following inoculation into healthy onion bulbs and incubation for 1 week at either 37 or $28^{\circ} \mathrm{C}$. One species, Leuconostoc citreum, was fully pathogenic in onion bulbs at $18^{\circ} \mathrm{C}$; occasionally (30\% success rate), it caused leaf lesions on inoculated onion plants incubated at $18^{\circ} \mathrm{C}$ (data not shown).

Two accounts exist of LAB as postharvest pathogens of fruit and vegetables, A single observation was communicated in two reports from the United Kingdom in the 1970s by Taylor and associates (Taylor and Dudley 1975; Taylor and Holden 1977). They described a bacterial rot of storage onions caused by a Lactobacillus species, which, based on biochemical and serological tests, was presumed to be L. plantarum. As described, "the bacterium caused severe water soaking of the internal tissues on onion bulbs but only at high temperatures (approximately $35^{\circ} \mathrm{C}$ )." The present results are consistent with Taylor's observations. In the second report, Leuconostoc mesenteroides was shown to cause a postharvest decay of tomato (Conn et al. 1995). The authors tested pathogenicity on several different harvested fruits and vegetables, including onion bulbs. In their test, Leuconostoc mesenteroides did not cause decay in onion bulbs, even after incubation for 14 days. The discrepant results could be due to the incubation temperature $\left(20^{\circ} \mathrm{C}\right)$ used in the tomato study or, as the authors suggested, the adaptation of their strain to its niche in tomato fruits or perhaps differences in capabilities among the strains tested here and those tested earlier.

Nevertheless, in this study strains of Leuconostoc mesenteroides of diverse origin (onion and dairy sources) caused mild water soaking and discoloration in inoculated bulbs incubated at $18^{\circ} \mathrm{C}$ about $44 \%$ of the time. When incubated at 28 or $37^{\circ} \mathrm{C}$, all inoculated bulbs exhibited water soaking and distinct discoloration after incubation for 7 days.

Based on the present work, several closely related species of LAB are capable of rotting onion bulbs. Previously, all the known species
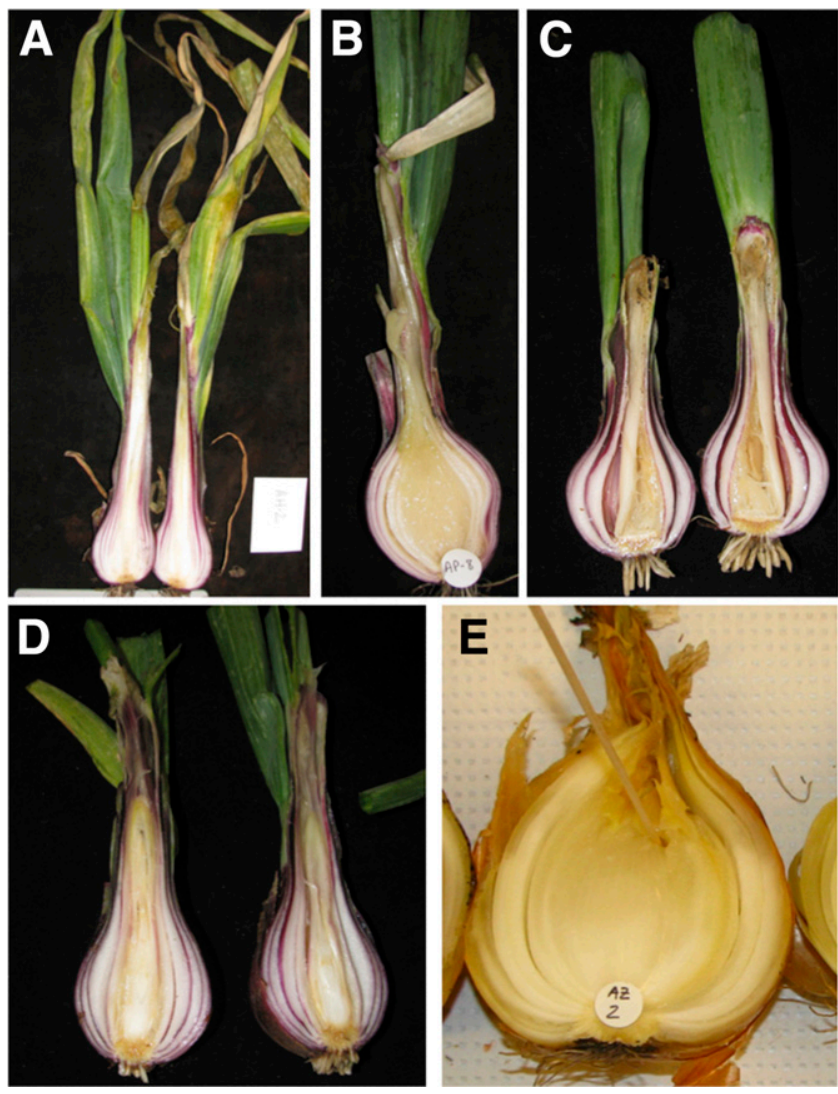

Fig. 1. Diseased onion plants collected from commercial growers from 2013 through 2015 from which lactic acid bacteria were recovered. A, Red onion from Elba, NY; B, Onion variety Red Wing from Orange Co., NY; C and D, Red onions from Oregon; E, Freshly harvested bulb, variety Braddock, from Orange Co., NY. of bacteria capable of rendering onion bulbs unmarketable (Schwartz 2008) were gram-negative, except for the sole gram-positive bacterium reported by Taylor et al. (Taylor and Dudley 1975; Taylor and Holden 1977) (Lactobacillus species). Some species of LAB can rot bulbs at relatively low temperatures, similar to those that may occur in storage facilities that use ambient air to cool stored bulbs. Therefore, the ability of Leuconostoc citreum to reliably rot onion bulbs at such temperatures could be problematic for growers.

In addition to being able to rot mature onion bulbs, several of the strains tested here were also good pathogens of onion leaves at warm temperatures and occasionally at lower temperatures. In spite of the rather ubiquitous occurrence of $\mathrm{LAB}$ in association with plants, we are unaware of previous reports of LAB causing disease of the foliage of any plant. Furthermore, interestingly, leaf lesion elicitation by the gram-positive $\mathrm{LAB}$ was restricted to the second or third youngest leaves of onions and not older or younger leaves. This leaf specificity contrasts with the ability of two well-studied gram-negative bacterial onion pathogens, $P$. ananatis and $B$. cepacia, which can produce symptoms on any leaf regardless of its developmental stage. This suggests that the mechanism of lesion elicitation by the various LAB tested is similar but differs from that of the gram-negative pathogens of onion. Alternatively, onion leaves may be particularly susceptible to bacterial infection at their middle stage of development.

Tissue maceration was not observed in leaves or bulbs under the controlled conditions of laboratory inoculations. The symptoms of field plants on arrival in the lab varied from those that resulted from laboratory inoculations. Symptomatic field plants often had macerated internal tissues associated with the diseased center leaves. The lag time between leaf infection by LAB and symptoms becoming evident to a grower may have allowed secondary organisms to enter the infection court. Alternatively, LAB may not be primary pathogens and may arrive as secondary invaders of diseased tissue. To clarify, future studies should include scouting of fields for plants exhibiting symptoms of leaf blight consistent with those observed in the lab. Also, isolation should be attempted from such plants and inoculations should be made in the field with LAB.

The distribution and population sizes of LAB in an onion field are unknown. However, it is generally accepted that, while ubiquitous in the environment, epiphytic populations of LAB on field plants are
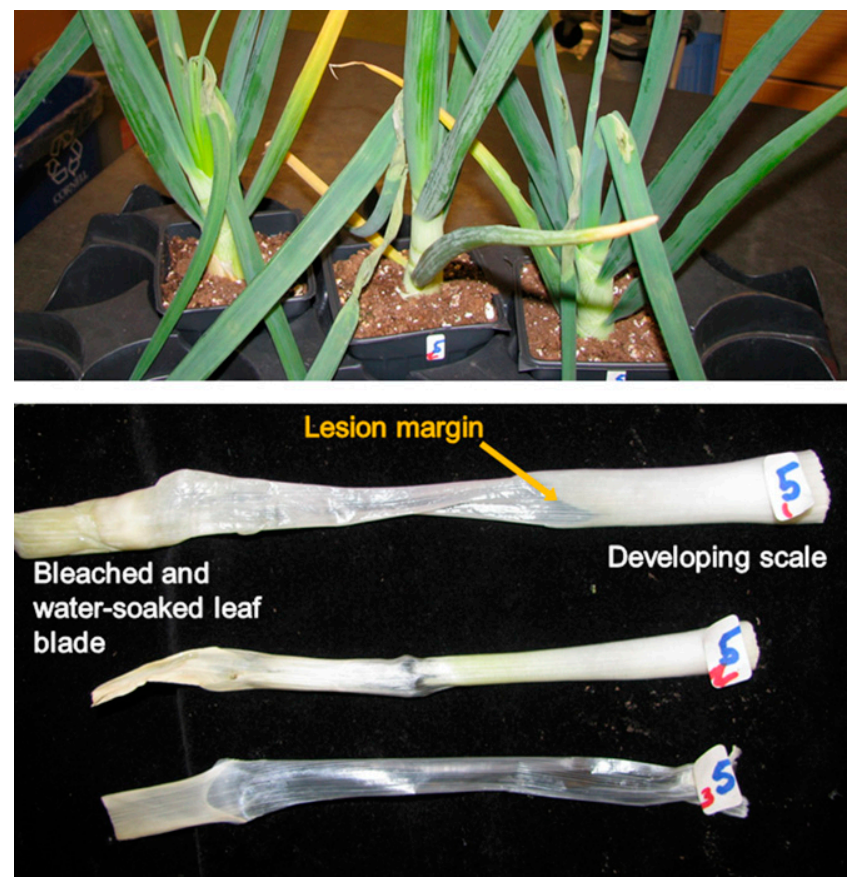

Fig. 2. Leaf symptoms caused by $L$. pseudomesenteroides strain $A H 2 c$. Top, onion plants inoculated with strain $\mathrm{AH} 2 \mathrm{C}$ and incubated at $32^{\circ} \mathrm{C}$ for $48 \mathrm{~h}$. Bottom, lesion margins of inoculated leaves dissected from the same plants after 19 days incubation at $32^{\circ} \mathrm{C}$ 
low (Rooke 1990; Stirling and Whittenbury 1963). The mechanism by which the LAB might enter plants is also unknown. However, it is presumed that, like most bacterial plant pathogens, a wound caused by mechanical damage from wind, hail, insect feeding, or the like facilitates entry into the plant. LAB are reported to be common residents of insect guts (Groenewald et al. 2006), and at least one bacterial onion pathogen, $P$. ananatis, has been shown to be transmitted by Thrips tabaci, through bacteria-laden fecal deposits entering wounds created by insect feeding (Dutta et al. 2014).

Because LAB do not grow well on commonly used selective and general media intended for culturing gram-negative bacteria from onions, LAB may be a more common pathogen of onion plants than the current literature indicates. As warm temperatures favor symptom development from the several bacteria tested here, LAB may become more of a problem if the current trend of increasing temperatures during the growing season continues. In this study, a diverse group of LAB was isolated in three consecutive years from symptomatic field plants in two very different growing regions. Both strains from symptomatic onions grown on the drained swampland in humid continental New York and strains from mineral soil in desert-like conditions of northeastern Oregon caused disease in leaves of growing onions and harvested bulbs. In addition, several strains of the same LAB, isolated from dairy products, proved similarly pathogenic to onions.

\section{Acknowledgments}

We acknowledge funding in support of this study provided by New York State (NYS) Specialty Crops block grants, the United States Department of Agriculture Multi-State Regional Hatch project W-2008 for research on iris yellow spot virus, thrips, and other diseases of onion, the NYS Onion Research and Development Program, The New York Farm Viability Institute, and Cornell University. We thank A. Kocot (Harvest Queen Farms, Florida, NY), R. Minkus (Minkus Family Farms, New Hampton, NY), B. Dean (River Point Farms, Hermiston, OR), and C. A. Hoepting (Cornell Cooperative Extension, Albion NY), for gifts of symptomatic onions. We thank the Cornell University Food Safety Laboratory and Milk Quality Improvement Program for gifts of dairy-product derived strains of LAB.

\section{Literature Cited}

Azcárate-Peril, M. A., and Raya, R. R. 2001. Methods for plasmid and genomic DNA isolation from Lactobacilli. Pages 135-139 in: Food Microbiology Protocols, Vol. 14. J. F. T. Spencer and A. L. de Ragout Spencer, eds. Humana Press, New York.

Bonasera, J. M., Asselin, J. E., and Beer, S. V. 2014. Identification of bacteria pathogenic to or associated with onion (Allium cepa) based on sequence differences in a portion of the conserved gyrase B gene. J. Microbiol. Methods 103:138-143.
Carr, E. A., Zaid, A. M., Bonasera, J. M., Lorbeer, J. W., and Beer, S. V. 2013. Infection of onion leaves by Pantoea ananatis leads to bulb infection. Plant Dis. 97:1524-1528.

Conn, K. E., Ogawa, J. M., Manji, B. T., and Adaskaveg, J. E. 1995. Leuconostoc mesenteroides subsp mesenteroides, the first report of a coccoid bacterium causing a plant-disease. Phytopathology 85:593-599.

Dutta, B., Barman, A. K., Srinivasan, R., Avci, U., Ullman, D. E., Langston, D. B., and Gitaitis, R. D. 2014. Transmission of Pantoea ananatis and $P$. agglomerans, causal agents of center rot of onion (Allium cepa), by onion thrips (Thrips tabaci) through feces. Phytopathology 104:812-819.

Elliker, P. R., Anderson, A. W., and Hannesson, G. 1956. An agar culture medium for lactic acid Streptococci and Lactobacilli. J. Dairy Sci. 39:1611-1612.

Groenewald, W. H., Van Reenen, C. A., Todorov, S. D., Toit, M. D., Witthuhn, R. C., Holzapfel, W. H., and Dicks, L. M. T. 2006. Identification of lactic acid bacteria from vinegar flies based on phenotypic and genotypic characteristics. Am. J. Enol. Vitic. 57:519-525.

Ranieri, M. L., and Boor, K. J. 2009. Short communication: Bacterial ecology of high-temperature, short-time pasteurized milk processed in the United States. J. Dairy Sci. 92:4833-4840.

Rooke, J. A. 1990. The numbers of epiphytic bacteria on grass at ensilage on commercial farms. J. Sci. Food Agric. 51:525-533.

Ross, R. P., Morgan, S., and Hill, C. 2002. Preservation and fermentation: Past, present and future. Int. J. Food Microbiol. 79:3-16.

Schaad, N. W. 2001. Laboratory guide for identification of plant pathogenic bacteria. N. W. Schaad, J. B. Jones, and W. Chun, eds. APS Press, St. Paul, MN.

Schleifer, K.-H. 2009. Phylum XIII. Pages 19-1317 in: Bergey's Manual of Systematic Bacteriology: The Firmicutes. Vol. 3. P. Vos, G. M. Garrity, D Jones, N. R. Krieg, W. Ludwig, F. A. Rainey, K.-H. Schleifer, and W. B. Whitman, eds. Springer, New York.

Schroeder, B. K., du Toit, L. J., and Schwartz, H. F. 2009. First report of Enterobacter cloacae causing onion bulb rot in the Columbia Basin of Washington State. Plant Dis. 93:323.

Schwartz, H. F. 2008. Compendium of onion and garlic diseases and pests. Schwartz, H. F., and Mohan, S. K., eds. APS Press, St. Paul, MN.

Shrestha, A., Kim, B. S., and Park, D. H. 2014. Biological control of bacterial spot disease and plant growth-promoting effects of lactic acid bacteria on pepper. Biocontrol Sci. Technol. 24:763-779.

Stirling, A. C., and Whittenbury, R. 1963. Sources of the lactic acid bacteria occurring in silage. J. Appl. Bacteriol. 26:86-90.

Taylor, J. D., and Dudley, C. L. 1975. Pages 115-117 in: 25th Annual Report for 1974, National Vegetable Research Station. The British Society for the Promotion of Vegetable Research, Wellesbourne, Warwick, U.K.

Taylor, J. D., and Holden, C. M. 1977. Page 104 in: 27th Annual Report for 1976, National Vegetable Research Station. The British Society for the Promotion of Vegetable Research, Wellesbourne, Warwick, U.K.

Van Baarlen, P., and Siezen, R. J. 2009. Genomics of plant-associated microbes. Microb. Biotechnol. 2:406-411.

Weisburg, W. G., Barns, S. M., Pelletier, D. A., and Lane, D. J. 1991. 16S ribosomal DNA amplification for phylogenetic study. J. Bacteriol. 173:697-703.

Zaid, A. M., Bonasera, J. M., and Beer, S. V. 2012. OEM-A new medium for rapid isolation of onion-pathogenic and onion-associated bacteria. J. Microbiol. Methods 91:520-526. 